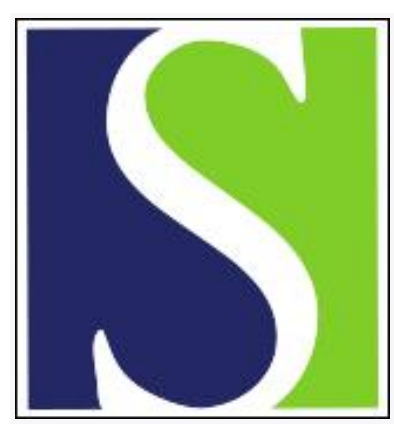

Scand J Work Environ Health 2001;27(5):353

https://doi.org/10.5271/sjweh.625

Issue date: Oct 2001

\title{
Deaths from pneumonia after welding
}

by Wergeland $E$, Iversen $B G$

This article in PubMed: www.ncbi.nlm.nih.gov/pubmed/11712617

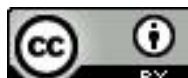

This work is licensed under a Creative Commons Attribution 4.0 International License 


\section{Deaths from pneumonia after welding}

The Norwegian Labour Inspection Authority (NLIA) has issued a warning to Norwegian physicians about the potentially lethal risk associated with the inhalation of fumes from thermal metal work (1). Physicians suspecting pneumonia in patients who are employed are urged to ask about recent occupational exposures. Pneumonia after exposure to fumes from welding, cutting, or grinding may require hospitalization. Doctors are also warned against dealing with metal fume fever as a harmless condition. This flu-like syndrome, which is familiar to many welders, indicates excessive exposure. It involves an inflammatory pulmonary reaction that may promote serious infections. The symptoms may also mask an emerging pulmonary edema.

The warning follows three independent reports of deaths from pneumonia with septicemia to the NLIA since 1997 among previously healthy men 50 to 55 years of age. All three men were exposed to welding fumes immediately before they fell ill. Two were experienced shipyard welders. According to their widows, they used to have bouts of metal fume fever several times a year. The third worked as an accountant until half a year before his death, when he was made redundant. He found new employment as a helper in a workshop for the reconstruction of heavy trucks, and he occasionally assisted other workers who were welding on the chassis. He had not complained of adverse reactions related to this work.

The NLIA has also received reports of nonfatal pneumonia after exposure to fumes from cutting, grinding, and welding. On one occasion, three workers were hospitalized with lobar pneumonia, while six were treated as outpatients for lower-respiratory tract infection, after reconstruction work inside the hull of a ship (2).

Fatal outcome from bacterial pneumonia is rare among middle-aged men, and it is usually associated with some underlying disease. Among men 50 to 59 years of age in Norway in 1997, three deaths were recorded as due to pneumonia or influenza (ICD10 J1018) and four were due to streptococcal septicemia (ICD10 A400-409) (Statistics Norway, Causes of Death 1997, available from http://www.ssb.no). The three deaths reported after welding over a few years' time therefore indicate that the inhalation of welding fumes may seriously aggravate the prognosis of pneumonia.
Coggon et al (3) observed increased mortality from pneumonia in England and Wales among welders aged 15-64 years and suggested that lobar pneumonia be considered an occupational disease. We may be rediscovering what was common knowledge before the era of antibiotics. Chavigny (4) described "pneumonie à marche aiguë", together with rapidly developing pulmonary edema in 1937 as "la maladie des soudeurs" (welders' disease), sometimes with fatal outcome.

Fumes from thermal metal work contain several possible causal agents. Nitrous oxides and ozone, irritant gases formed by the oxidation of nitrogen, and photolysis of oxygen in ambient air are known causes of pulmonary edema. Oxides from manganese, zinc, or copper in the metal alloy or coating material can elicit metal fume fever. Manganese has also long been considered to increase susceptibility to pneumonia. Various compounds formed by the thermal decomposition of surface coating may be involved.

\section{References}

1. Wergeland E. Pneumonidødsfall av sveiserøyk? [Pneumonia deaths caused by welding fumes?] Oslo: National Institute of Public Health 2001:29:4. MSIS-rapport.

2. Fossum T, Espeland O, Hobbesland A. Health effects and exposure assessments by work on Geco Angler April 1998. [Helseeffekter og eksponeringsvurderinger ved arbeid på "Geco Angler" april 1998.] Skien: Department of occupational and environmental medicine, Telemark County Hospital; 1999.

3. Coggon D, Inskip H, Winter P, Pannett B. Lobar pneumonia: an occupational disease in welders. Lancet 1994;344:41-3.

4. Chavigny P. La maladie des soudeurs. Ann Méd Leg 1937;17:1083-4.

\section{Ebba Wergeland,}

Norwegian Labour Inspection Authority

P.b.8103 Department

N-0032 Oslo Norway

[e-mail:ebba.wergeland@arbeidstilsynet.dep.no]

Bjørn G Iversen,

National Institute of Public Health

P.b.4404 Nydalen

N-0403 Osio Norway

[e-mail:bjorn.iversen@folkehelsa.no] 